\title{
A new stem fossil characid (Teleostei: Ostariophysi) from the Eocene-Oligocene of southeastern Brazil
}

\author{
Fernanda E. Weiss ${ }^{1}$, Maria Claudia Malabarba ${ }^{1,2}$ and Luiz R. Malabarba ${ }^{1,2}$
}

A new characiform is herein described from the Eocene-Oligocene sediments exposed in the Aiuruoca basin, in southern Minas Gerais State, Brazil. Recently, two other characid species were described for this same fossil level: $\uparrow$ Paleotetra aiuruoca and $\dagger$ Paleotetra entrecorregos. The holotype of this new characiform is represented by an articulated specimen preserved as part and counterpart, in which the most anterior part of the head is missing, including the jaws. Despite the lack of the diagnostic characters from the snout, a unique combination of characters allows its differentiation from other Neotropical characiforms, raising a new genus and species: †Bryconetes enigmaticus. Among these characters are: the presence of a supraorbital, dentary with inflated pentacuspidate teeth arranged in a single row, infraorbital 3 expanded and ornamented with punctuations and grooves, a large anal fin with iii+22-23 rays, and the caudal fin with 11 ventral procurrent rays of which the anteriormost are fused in laminar bones. A phylogenetic analysis using morphological data was performed and recovered $†$ Bryconetes enigmaticus as a stem group to characiforms lacking a supraorbital. Based on the results of this analysis, a discussion of the potential relationships of the new taxon with other characiforms is presented.

Um novo caraciforme é descrito a partir de sedimentos do Eoceno - Oligoceno expostos na bacia de Aiuruoca , no sul de Minas Gerais, Brasil. Recentemente, outras duas espécies de Characidae foram descritas para este mesmo nível fossilífero: †Paleotetra aiuruoca e †Paleotetra entrecorregos. O holótipo do novo caraciforme é representado por um espécime articulado preservado como parte e contraparte, do qual falta a parte mais anterior da cabeça, incluindo mandíbula e maxila. Apesar da falta dos caracteres diagnósticos do focinho, uma combinação única de caracteres permite diferenciá-lo dos outros Characiformes neotropicais, levando a descrição de um gênero e espécie novos: †Bryconetes enigmaticus. Entre esses caracteres estão a presença de um supra-orbital, dentário com dentes pentacuspidados dispostos em uma única fileira, infraorbital 3 expandido e ornamentado com pontuações e sulcos, nadadeira anal com iii,22-23 raios e nadadeira caudal com 11 raios procurrentes ventrais sendo os mais anteriores fundidos em ossos laminares. A análise filogenética recuperou †Bryconetes enigmaticus como um "stem-grupo" de Characiformes sem supraorbital. Com base nestes resultados discutem-se as possíveis relações da nova espécie com outros Characiformes.

Key-words: Aiuruoca, Eocene, Paleotetra, stem-group, supraorbital.

\section{Introduction}

The order Characiformes is the largest Neotropical freshwater fish group and one of the most diverse groups of actinopterygians, with more than 2000 species (Eschmeyer \& Fong, 2014). Extant forms are widely distributed through Africa and South and Central America freshwaters, occurring also in southern North America. Although occurring in both sides of the Atlantic, the characiforms are much more diversified in the Neotropical region where 1830 species are registered, versus only 227 African species (Eschmeyer \& Fong, 2014). Their modern distribution and fossils document the historical connection between Africa and South America, which when associated with their extreme diversity and restriction to freshwaters, makes characiforms an excellent group to investigate explanations for the composition and distribution of the modern Neotropical ichthyofauna.

The occurrence of fossils unambiguously assignable to the order is restricted to Africa, South America, Europe and the Arabian Peninsula (Malabarba \& Malabarba, 2010; Arroyave et al., 2013). Fossils assignable to Neotropical characiform lineages have not been found in Africa or vice

\footnotetext{
${ }^{1}$ Programa de Pós-Graduação em Biologia Animal and ${ }^{2}$ Departamento de Zoologia, Universidade Federal do Rio Grande do Sul, Av. Bento Gonçalves, 9500. Porto Alegre 91501-970, Rio Grande do Sul, Brazil. fewebr@yahoo.com.br (FEW), claudia.malabarba@ufrgs.br (MCM), malabarb@ufrgs.br (LRM)
} 
versa, being the Neotropical fossil records referable to the Erythrinidae, Curimatidae, Serrasalmidae, Bryconidae, Triportheidae, and Characidae (Malabarba \& Malabarba, 2010; Weiss et al., 2012). In Brazil, fossil characiforms are recorded from the Upper Cretaceous of the Paraná Basin (Bertini et al., 1993), the Tertiary of the Taubaté Basin (Woodward, 1898; Schaeffer, 1947; Travassos \& Santos, 1955; Malabarba, 1998), the Tertiary of the Maranhão Basin (Silva Santos, 1946), the Neogene of Acre (Richter, 1984; Malabarba \& Dutra, 2002; Gayet et al., 2003), and the Eocene-Oligocene of the EntreCórregos Formation, in eastern Brazil (Weiss et al., 2012).

The relationships among the Characidae members, the richest family in the order, are so indefinite that two thirds of the species were listed as incertae sedis taxa in Reis et al. (2003). Recently, phylogenetic studies have investigated these relationships, either using morphological (Mirande, 2010) or molecular (Calcagnoto et al., 2005; Javonillo et al., 2010; Oliveira et al., 2011) data, but the results obtained are only partially congruent. Among these studies, those using fossils to calibrate the divergences times also provide tests to the vicariant model as explanation for the disjunct distribution of the characiforms (Arroyave et al., 2013). In this scenario, fossil characids properly dated and phylogenetically positioned are fundamental to performing more analyses.

We herein describe a new teleost species based on a fossil material from the Entre-Córregos Formation, Tertiary of Minas Gerais States, southeastern Brazil. The new taxon is clearly a characiform, but its relationships with the other members of this order are uncertain. Although, presenting a good fossilization on the whole, the holotype lacks the snout, an essential region to establish relationships within characiforms. Then, the possible relationships of the fossil species are tentatively discussed based on part of the head, two teeth, and on the caudal fin skeleton. Aside from that, $†$ Bryconetes enigmaticus presents diagnostic characters that allows its distinction from the other characiform fossil taxa of this formation: $\uparrow$ Paleotetra aiuruoca and $\uparrow P$. entrecorregos.

\section{Geological and paleoenvironmental setting}

The Paleogene Aiuruoca basin is located in southern Minas Gerais State $\left(44^{\circ} 15^{\prime} \mathrm{W}-44^{\circ} 45^{\prime} \mathrm{W}\right.$ and $\left.22^{\circ} 15^{\prime} \mathrm{S}-21^{\circ} 30^{\prime} \mathrm{S}\right)$, near the borders of São Paulo and Rio de Janeiro states (Fig.1), in the drainage area of the Aiuruoca River. This is a taphrogenic basin whose origin was related to the tectonic events initiated at the end of the Mesozoic involved in the continental rifting of southeastern Brazil and the opening of the Atlantic ocean (Ricominni et al., 2004; Santos et al., 2006). This basin includes two lithostratigraphic units (Santos, 1999): the Pinheirinho Formation, representing an alluvial fan paleoenvironment; and the Entre-Córregos Formation, the lacustrine facies from where the material here described was collected.

The Entre-Córregos Formation presents fossil levels containing plants (leaves, stems, small fruits, and trunks), insects, fishes, amphibians and coprolites. Based on the palynological content, Garcia et al. (2000) assigned an EoceneOligocene age to this formation. The collecting site is located
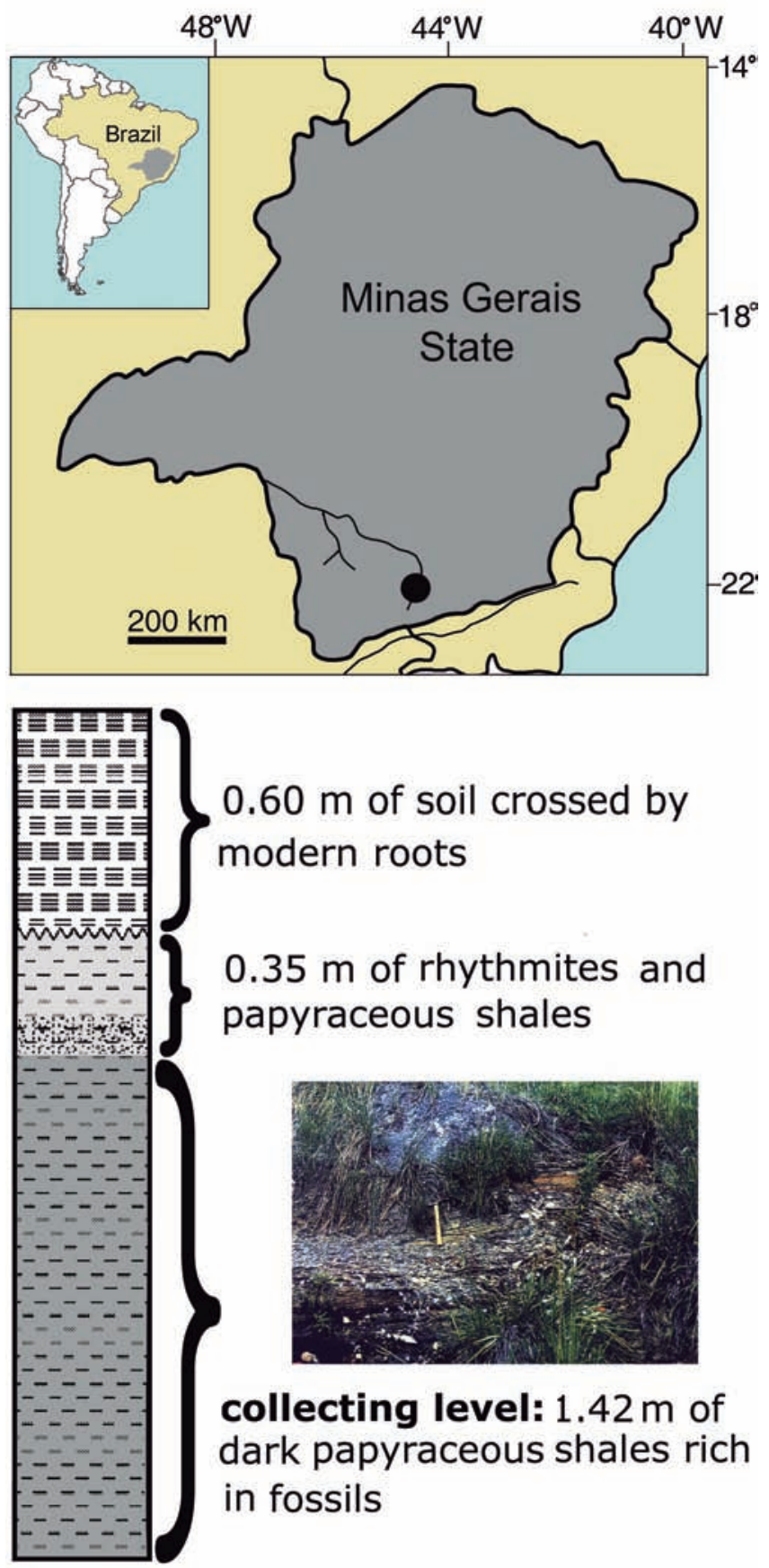

Fig. 1. Location map. A, map showing the location of the fossil site (black circle) in southern Minas Gerais State, southeastern Brazil; B, stratigraphic column and image of the Entre-Córregos Formation outcrop, type locality for $†$ Bryconetes enigmaticus. Modified from Santos (1999) and CastroFernandes et al. (2013).

at $1080 \mathrm{~m}$ of altitude on the left margin of the Entre-Córregos stream, where a layer with 1.4 meter thick level of dark gray papyraceous shales rich in fossils crops out. Its fossil content includes plants (some fruits, seeds and leaves), insects, a bird feather, pipid frogs and fishes. This fossiliferous layer is overlaid by few centimeters of rhythmites poor in fossils and 
topped with soil crossed by modern roots (Castro-Fernandes et al., 2013).

The fossil fishes from the Entre-Córregos Formation present a very good preservation and belong to freshwater families: Cichlidae and Characidae. Most of the fish specimens are complete and articulated, including some bones and teeth, besides several impressions of young and very small undetermined individuals (Malabarba, 2004; Malabarba \& Malabarba, 2008; Weiss et al., 2012). These facts associated to data from palynomorphs, plants, insects and vertebrates suggest that the Entre-Córregos Formation was deposited in a lake, relatively large and calm under reducing environmental conditions (Santos, 1999; Garcia et al., 2000; Bedani \& Haddad, 2002; Delgado \& Bernardes-de-Oliveira, 2004). The high concentration of fossils, as well as the good quality of preservation and the proximity to diamictites suggest syngenetic catastrophic events (Santos et al., 2006). Palynological data associated with foliar architectural features of the taphoflora point out a scenario of a very wet tropical forest under high temperatures (Garcia et al., 2000; CastroFernandes et al., 2013) during the deposition of this formation.

\section{Material and methods}

The fossil material herein described belongs to the fish collection of the Department of Zoology of the Universidade Federal do Rio Grande do Sul (UFRGS), in Porto Alegre, Brazil. It is constituted of two specimens designated as holotype (UFRGS 19114) and paratype (UFRGS 19187). The holotype is represented by an articulated specimen, in which is missing the most anterior part of the head, including snout and most part of the jaws (Fig. 2A). The preservation as part and counterpart would be common if it was not for an unusual feature: all the bones are preserved articulated in one of the sides (part) of the fossil, except by the snout which is missing. In the other side of the fossil (counterpart), there is no elements preserved, only the feeble cast of the entire specimen including the most anterior region of the head. Then, although the details about the jaw bones and teeth cannot be determined, the overall morphology and proportions of this region can be observed in the counterpart cast. In order to make easy for examining, illustrating and taking measurements a latex peel in this cast was made and coated with ammonium chloride (Fig. 2B). The paratype is poorly preserved as disarticulated remains of an individual, whose identification was based on the infraorbital 3 and preopercle morphologies. Despite the quality preservation of the paratype, the presence of the dentary with the teeth contributed to the codification of some important characters in the matrix.

The photographs were taken using a Canon EOS 7D digital camera with macro lenses. A vertebra and a tooth were examined under a Scanning Electron Microscope (SEM) after coated with carbon and gold.

Institutional abbreviations are: UFRGS - Universidade Federal do Rio Grande do Sul, Porto Alegre, Brazil; UNG Universidade de Guarulhos, Guarulhos, Brazil.
Morphometric data (Table 1) were taken following Fink \&Weitzman (1974). In the counts of fin rays, lower case Roman numerals indicate unbranched rays, and Arabic numerals indicate branched rays. Nomenclature mostly follows Weitzman (1962), with some modifications suggested by subsequent authors (Fink \& Fink, 1981; 1996; Zanata \&Vari, 2005): mesethmoid instead of ethmoid, vomer instead of prevomer, epioccipital instead of epiotic, endopterygoid instead of mesopterygoid.

For this study, material of the fossil species was coded (Appendix 1) and added to the morphological matrix of Mirande (2010), with 365 characters and 160 species of the Characidae (sensu Reis et al., 2003) and outgroups. Since the snout is a crucial site in identifying characids, the lack of this region in †Bryconetes enigmaticus, prevented us to code important diagnostic characters for this matrix, in such a way only 169 characters were coded and 196 characters remained as missing (?). The analysis was performed using TNT (New Technology search; using sectorial search, ratchet, drift and tree fusing options; max. tree: 10,000; find minimum length five times). We further tested results obtained from the implicit weight analysis as done by Mirande (2010).

\section{Systematic Palaeontology}

\section{Ostarioclupeomorpha Arratia, 1997 Ostariophysi (sensu Fink \& Fink 1996) Characiformes (sensu Fink \& Fink 1996)}

\section{Bryconetes n. gen.}

Diagnosis. A characiform distinguished by the presence of a supraorbital not contacting the infraorbital 6 , by the third infraorbital marked by diminutive punctuations and radial shallow grooves in its lateral surface, by the most anterior ventral procurrent caudal-fin rays fused in laminar medial bones, and by the possession of multicuspidate teeth, 36 vertebrae $(17 \mathrm{~A}+19 \mathrm{C})$, dorsal fin ii+9, anal fin long with iii+2223 rays.

Etymology. From the Greek, etes, meaning neighbor, and brycon, meaning noisy, a generic name that encompasses several characiform species.

\section{†Bryconetes enigmaticus n. sp.} Figs. 2-6

Diagnosis. Same as generic diagnosis (monospecific genus).

Etymology. From the Greek ainigma meaning something obscure, inexplicable, in allusion to the presence of striae in the infraorbital 3, a synapomorphy for the Characinae, in conjunction with a supraorbital bone and strong and inflated teeth that are not shared with the members of this subfamily. 

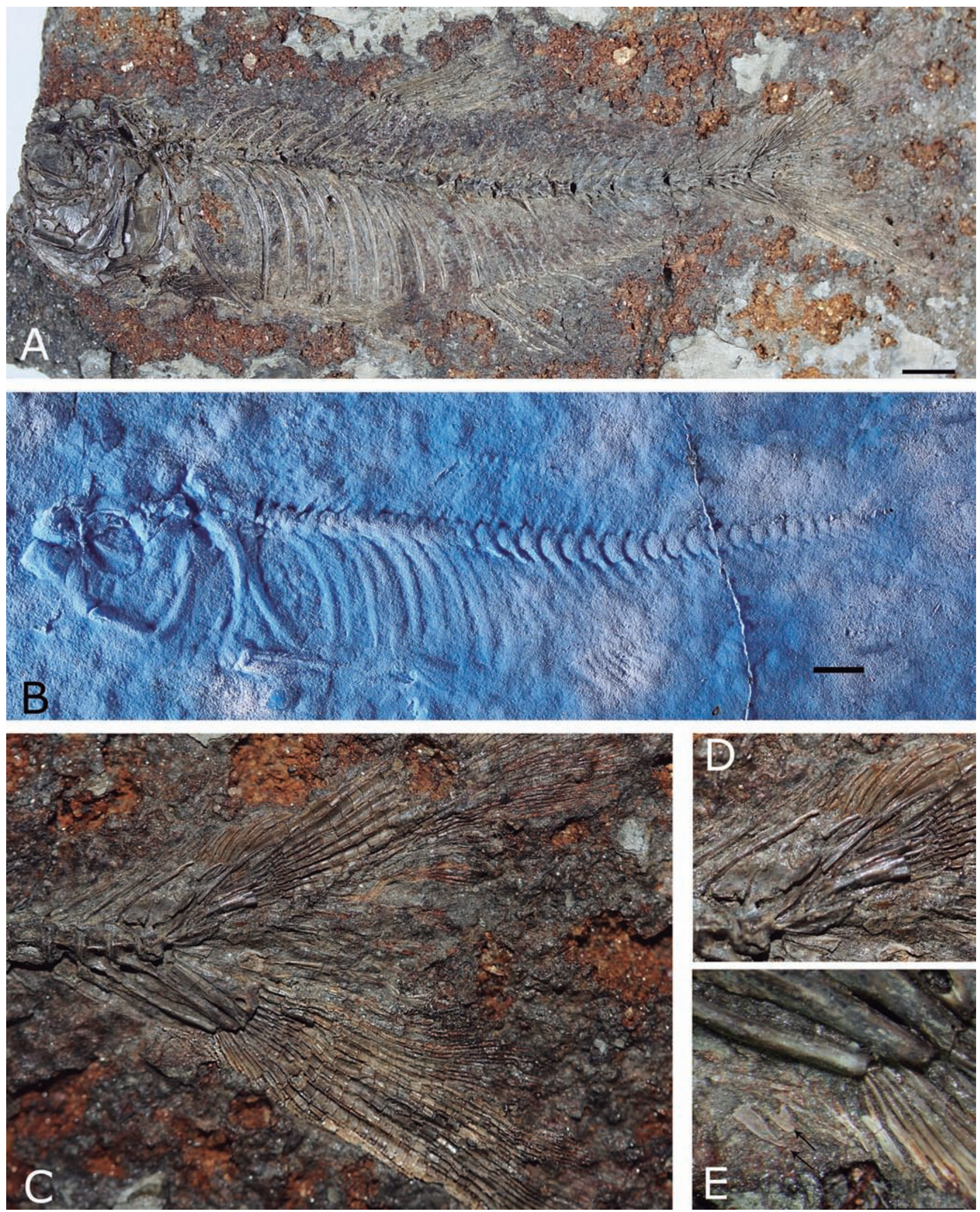

Fig. 2. †Bryconetes enigmaticus n. gen. n. sp., holotype, UFRGS 19114. A, fossil specimen as preserved in lateral view; B, silicone peel from the counterpart; $\mathbf{C}$, posterior part of the fish, with the caudal fin; D, enlargement of the caudal fin skeleton illustrating the modified neural arches and dorsal procurrent fin rays; $\mathbf{E}$, detail of the anteriormost ventral procurrent rays showing the fused laminar rays (arrows). Scale bars $=5 \mathrm{~mm}$. 
Holotype. UFRGS 19114, a single articulated specimen preserved in lateral view as part and counterpart, head lacking the snout (Fig. 2A; see Material and Methods section).

Paratype. UFRGS 19187, disarticulated and poorly preserved remains of an individual.

Type locality and age. Left margin of the Entre-Córregos stream, about $30 \mathrm{~km}$ northwest from Aiuruoca town, southern Minas Gerais State, Brazil. Entre-Córregos Formation, Aiuruoca Basin, Eocene-Oligocene (Garcia et al., 2000; Santos et al., 2006).

\section{Description}

General. †Bryconetes enigmaticus is a small and elongate characid, which reaches $75.2 \mathrm{~mm}$ in standard length (SL). Its morphometric and meristic data are given in the Table 1 . The dorsal profile of the head is slightly arched from the anterior end of premaxilla to the dorsal-fin origin; and ventrally slanted from this point to the caudal peduncle. The ventral profile is slightly arched from the dentary to the anal-fin origin. Posteriorly, the anal fin base is posterodorsally slanted towards the caudal peduncle; the dorsal and ventral margins of the caudal peduncle are slightly curved making it longer than deep. The greatest body depth is located at the vertical through the pelvic-fin insertion. The head represents $25.9 \%$ SL with an anterior and terminal mouth.

Skull. Besides the absence of its most anterior region, the skull is not well preserved (Fig. 3). The part of the skull roof that was fossilized is partially broken and collapsed. The elongate frontal has a smooth surface and a distinctly concave lateral border which forms the dorsal contour of the orbit. Anteriorly, between the divergent frontals, part of the mesethmoid is discernible. The parietals also has a smooth surface and is smaller than the parietal. The supraoccipital is partially visible showing remains of a posterior spine process which covers only the anterior vertical portion of the neural complex of Weberian apparatus. The canals and openings of the laterosensory system are partly preserved in the parietal and postparietal bones.

Ventrally, the lateral margin of the parietal forms with the sphenotic a well developed dilator fossa. In the pterotic there are two openings for the laterosensory canal: one posterior for the extrascapular canal and one anterior for the preopercular canal. Posteriorly, the pterotic contacts the extrascapular and also forms a spinelike process that projects
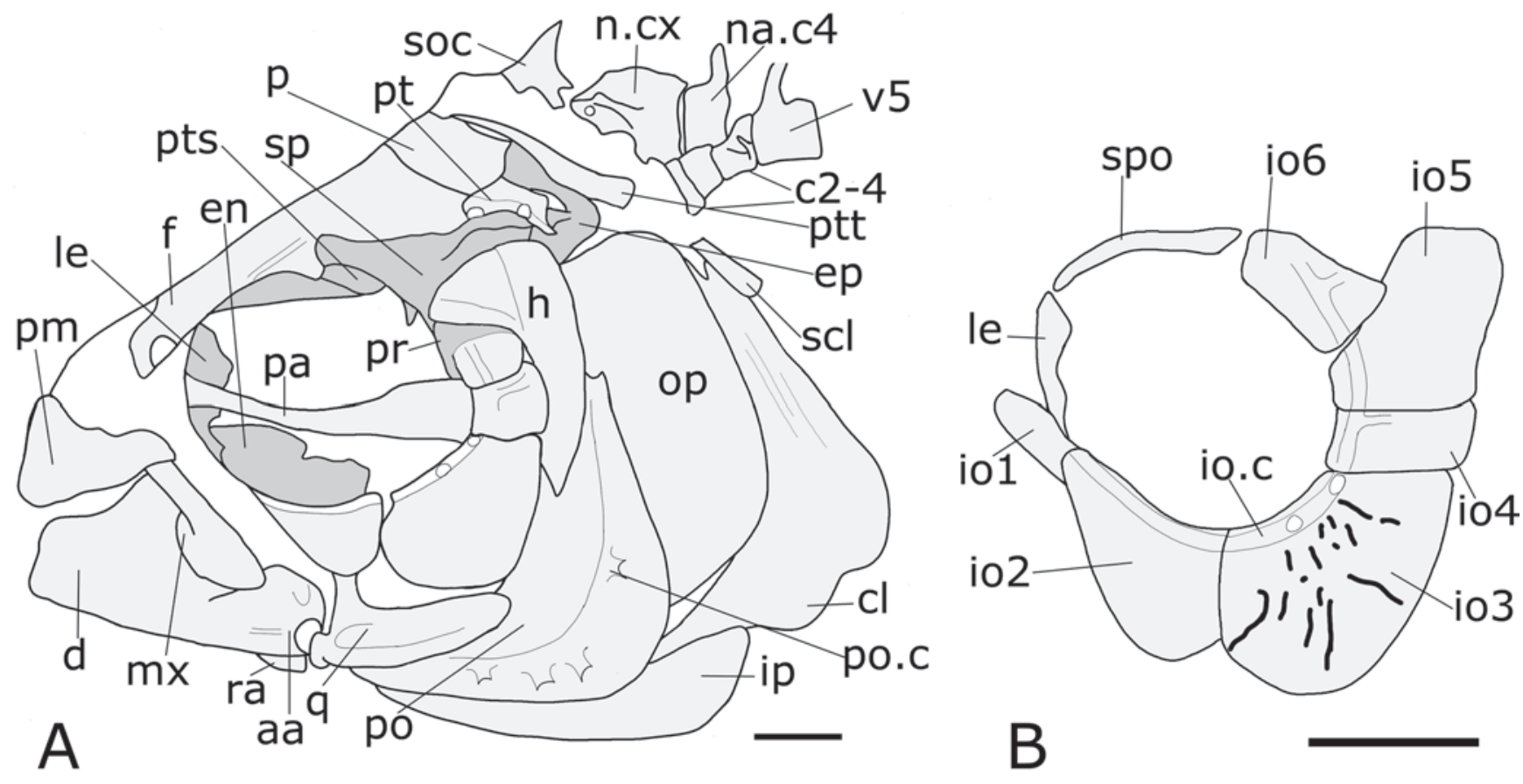

Fig. 3. Interpretative drawings for $\uparrow$ Bryconetes enigmaticus $n$. gen. n. sp. based on the holotype (UFRGS 19114) and a silicone cast of the counterpart. A, anterior region of the fish; B, circumorbital bones, showing the striae and punctuation from the neuromasts in the inforaorbital 3. Scale bars $=2 \mathrm{~mm}$. Abbreviations: aa, anguloarticular; c2-4, centra 2 to 4 (Weberian apparatus); cl, cleithrum; d, dentary; en, endopterygoid; ep, epiocipital; f, frontal; h, hyomandibular; io1-6, infraorbital 1 to 6; io.c, infraorbital sensory canal; ip, interopercle; le, lateral ethmoid; mx, maxilla; na.c4, neural arch of fourth vertebra; n.cx, neural complex; op, opercle; p, parietal; pa, parasphenoid; pm, premaxilla; po, preopercle; po.c, preopercular canal; pr, prootic; pt, pterotic; ptt, posttemporal; pts, pterosphenotic; q, quadrate; ra, retroarticular; scl, supracleithrum; soc, supraoccipital; sp, sphenotic; spo, supraorbital; v5, fifth vertebra. 
downward. From its posterior margin it is possible to observe part of the epioccipital with its anteriorly directed process crossing the posttemporal fossa.

In the orbit, there are remains of a small rhinosphenoid and a slender orbitosphenoid with the ventral margin distant from the parasphenoid. The parasphenoid is a slender and nearly straight bone, which crosses the orbit on its lower half. Anteriorly, it expands laterally and ascends slightly towards the vomer. The most anterior point of preservation in this fossil is the laminar lateral portion of the lateral ethmoid, which extends downwards from the anterior region of the parietal forming the anterodorsal wall of the orbit.

Snout and jaws. Although the snout is missing in $†$ Bryconetes enigmaticus, some information about the morphology of this region can be obtained from the impression in the counterpart of the fossil. By the counterpart cast we can describe the snout as strong and short, with a blunt outline and a terminal mouth. The jaws are about of the same size, but the lower jaw is more robust and prominent. In the silicone peel, a tubular nasal is visible.

The upper jaw is composed by the typical triangular premaxilla and the maxilla. The maxilla is elongated and almost straight with an expanded posteroventral region covering part of the lower jaw. Anteriorly, its tip is concealed by the premaxilla dentigerous process.

In the lower jaw, the dentary, anguloarticular and retroarticular are observable. The dentary is deep, robust and nearly rectangular, articulating to its contralateral at the symphyseal region by means of bony folds. In the anguloarticular it is possible observe part of the mandibular canal and the socket still in contact with the quadrate condyle. At its posteroventral corner, there is a small and triangular retroarticular.

The dentary dentition could be observed in the paratype (UFRGS 19187). Teeth in the dentary are strong and inflated with 5 cusps (Fig. 4), being arranged in one tooth row. The anteriormost teeth are the largest, decreasing sharply in size posteriorly.

Palatoquadrate and suspensorium. Although the dermal bones conceal most of the inner bones involved in the palatoquadrate and the suspensorium, some of them are visible enough to be described.

The quadrate has the typical characid shape with a strong condyle and two processes: one anterior directed dorsally and a longer ventral process, caudally directed. There is no foramen on the articular condyle of quadrate. The endopterygoid is observable below the parasphenoid within the orbit. It has a curved dorsal margin and lacks teeth. The hyomandibular is mainly represented by its fan-shaped dorsal portion which is partially covered anteriorly by the infraorbital 4 , and posteriorly by small fragments of the opercle. The hyomandibular ventral shaft is narrow and curved, covering part of the median border of the preopercle.

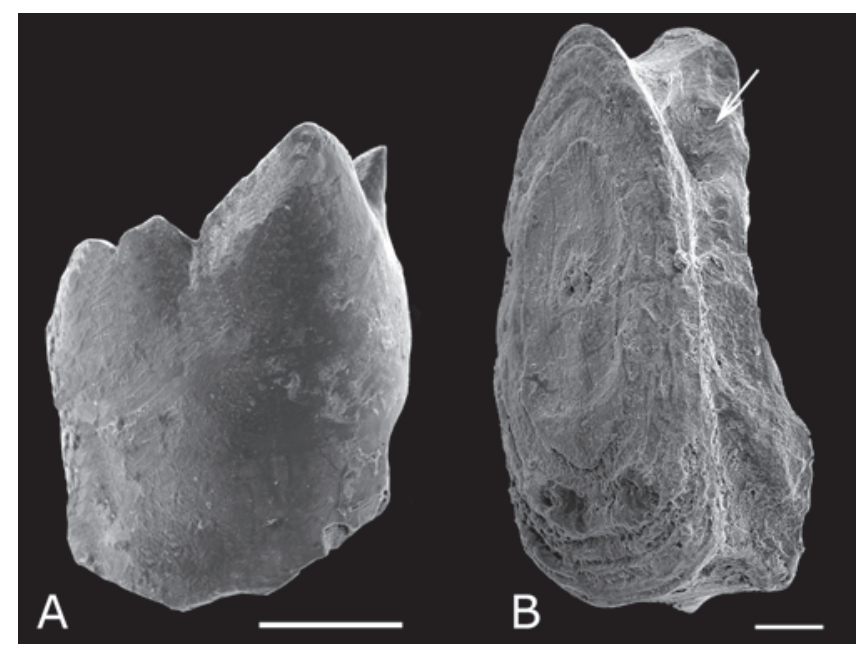

Fig. 4. †Bryconetes enigmaticus n. gen. n. sp., holotype, UFRGS 19114. A, a dentary tooth. B, first vertebra of Weberian apparatus. Arrow points to the facet for reception of scaphium. Scale bars $=200 \mu \mathrm{m}$.

Circumorbital series. Among the elements that usually outline the orbit only the infraorbitals 2-5 were fossilized; however the morphology of the other bones can be observed in the cast of the counterpart. A small and thin antorbital is the most anterior element of the circumorbital series. The narrow infraorbital 1 bears the anteroventral termination of the infraorbital laterosensory canal. The infraorbital 2 is triangular, expanded posteriorly, and articulates with infraorbital 3 along a short and straight suture. The third infraorbital is the largest element of the series, forming the posteroventral contouring of the orbit. Its posterior border just reaches the preopercle, and its lateral surface is marked by minute punctuations and shallow grooves mostly radially directed. The infraorbitals 4 is small and nearly squared.

The infraorbitals 5 and 6, along with the supraorbital, can only be observable from the counterpart. The infraorbital 5 is large, with the posterior region dorsoventrally expanded. The infraorbital 6 is rectangular and crossed by a branched infraorbital canal.

Despite there was no preservation of a supraorbital bone in the fossil, a narrow bone contouring the orbit anterodorsally is visible in the silicone peel of the counterpart (Figs. 2B, 3). Since it corresponds in shape and position to the supraorbital of Brycon meeki (Weitzman, 1962: fig. 8), we assume the presence of supraorbital in $\dagger$ Bryconetes enigmaticus.

Opercular apparatus. Despite of their damage, all bones of the opercular apparatus can be identified. The opercle is large and rectangular, twice deeper than wide. Its margins are straight and the posterior corners are slightly roundish. The preopercle is robust, boomerang shaped with a rounded posteroventral corner. A conspicuous sensory canal crosses it longitudinally, which opens in foramina and a few short branches. The interopercle and subopercle are narrow and 
nearly straight, following the ventral margin of the preopercle and opercle, respectively. The borders and surfaces of the bones in the opercular apparatus are smooth.

Supraneurals and axial skeleton. The vertebral column is straight with 36 vertebrae, 17 abdominals (including Weberian apparatus) and 18 caudals. There are 6 supraneurals, the first of them situated anterior to the dorsal tip of the neural spine of the fifth vertebra. Their shapes vary from narrow and elongated to slightly anteroposteriorly expanded in the dorsal tip as axe-shaped (an inverted “L”). Delicate and forked epineurals and epipleurals are preserved above and below the vertebral column, respectively.

Although the anterior region of the vertebral column is damaged, several elements of the Weberian apparatus can be recognized. The four centra are preserved, being the two first greatly foreshortened in comparison to the posterior ones. The neural complex is expanded with a concave posterior outline; a ridge extends dorsoventrally along its anterior region. The transverse process of neural arch of the third vertebra is short, not reaching the anterior margin of the tripus. Neural arch and spine of the fourth vertebra are fused to the centrum and articulated to the neural complex and to the neural arch of the third vertebra. There are remains of the claustrum, intercalarium and tripus.

Paired fins and girdles. The pectoral fin is badly damaged, but it is possible to identify some elements. A roughly triangular extrascapular is attached to the posterolateral part of the cranium with the anterodorsal opening through which the supratemporal canal passes into the parietal. The posttemporal is a long, ventrally expanded bone which includes a laterosensory canal segment. Dorsally, it ends in a spinous process directed to the posterior edge of the parietal; ventromedially, it bears a small spinelike process extending towards the intercalar.

The supracleithrum is elongated and preserved in medial view, being visible the inner fossa for the reception of the dorsal process of the cleithrum. The cleithrum is preserved in medial view. It is L-shaped, with a pointed dorsal tip and the posteroventral border projecting in a lamina forming a slight concavity. The scapula is represented only by a fragment preserved still sutured to the cleithrum base. The coracoid is low, not expanded, and with no signs of a bony ridge or coracoid foramen. No postcleithra were preserved.

The pectoral fin is long, its longest rays slightly surpassing the pelvic-fin origin. As the two fins were preserved superimposed, it is not possible do determine the shape or number of rays.

The pelvic fin is also poorly preserved. The pelvic bone is triangular (4.5 mm length), not bifurcate anteriorly, with a well-marked longitudinal ridge. Although it is not possible to count accurately the rays, they should not be more than 8 , and the longest rays reach two-thirds of the distance to the anal-fin origin. The rays of pelvic and pectoral fins have no hooks.
Median fins. The dorsal fin is positioned in the middle of the body, mostly opposite to the gap between the tip of pelvicfin rays and the origin of the anal fin. Rays in the dorsal fin $\mathrm{ii}+9$, the first branched ray is the longest, followed by progressively shorter rays (Fig. 5). There are 10 pterygiophores; the first of them is expanded distally, triangular and anteroventrally directed. The posteriormost pterygiophore supports the last two dorsal-fin rays.

The anal fin is long (Fig. 5), with its origin opposed to the last dorsal fin ray. There are iii $+22-23$ rays and 23 pterygiophores. The four anterior pterygiophores are fused with the corresponding medial radials; in the following pterygiophores the radials remain independent. The first pterygiophore is expanded in a bony lamina with a continuous margin, not notched; it supports the four anterior unbranched rays, which increase in size posteriorly. The following pterygiophores have just a narrow lamina anteriorly and posteriorly to their main body; each one supports a branched fin ray. The last rays are not completely preserved, not being possible to determine how many rays ( 1 or 2 ) articulate to the last pterygiophore. The anteriormost branched rays are the longest; the following ones reduce gradually in length caudally. There are no hooks on the rays.

Caudal fin. There are four vertebrae, including the terminal centrum, supporting the caudal fin (Fig. 6). There are two epurals, a paired uroneural, and six nearly triangular hypurals, which are autogenous except for the third. The hypural 1 is the largest, with a small gap separating it from the terminal centrum; the hypural 6 is the smallest and is slightly twisted. The posterior margin of hypural 3 is slightly deeper than that of hypural 4. The urostyle is robust, elongated and finishes posterodorsally in a sharp end. The parhypural is expanded anteroposteriorly and has a straight dorsal margin which is adjacent with the ventral margin of the hypural 1 . The modified neural process of the compound vertebra is short, laminar and expanded anteroposteriorly; its dorsal margin has a sharp projection along the urostyle. Anteriorly, its margin is slightly curved and serrated fitting the posterior margin of the also short and anteroposteriorly expanded neural process of the preural 2 centrum.

The caudal fin is large (22 $\mathrm{mm}$ ), homocercal, deeply furcated with equally sized and well defined lobes. There are 19 principal caudal-fin rays, 10 rays in the upper lobe plus 9 rays in the lower one; 10 dorsal and 11 ventral procurrent rays. The procurrent rays are situated in parallel; posteriormost ventral procurrent rays have separated lepidotrichia which are ventrally fused. The two most anterior ventral procurrent rays are medial laminar plates, nearly diamond shaped, with no remnants of the separated lepidotrichia; they are situated between haemal spines of the fourth and fifth preural centra.

Scales. Although fragmented, abundant cycloid and small scales (1.5 mm diameter) are impressed in different regions of the body, specially among the ribs. As no radii can be seen on any of these impressions, we are assuming that they should be absent or very reduced in number. 

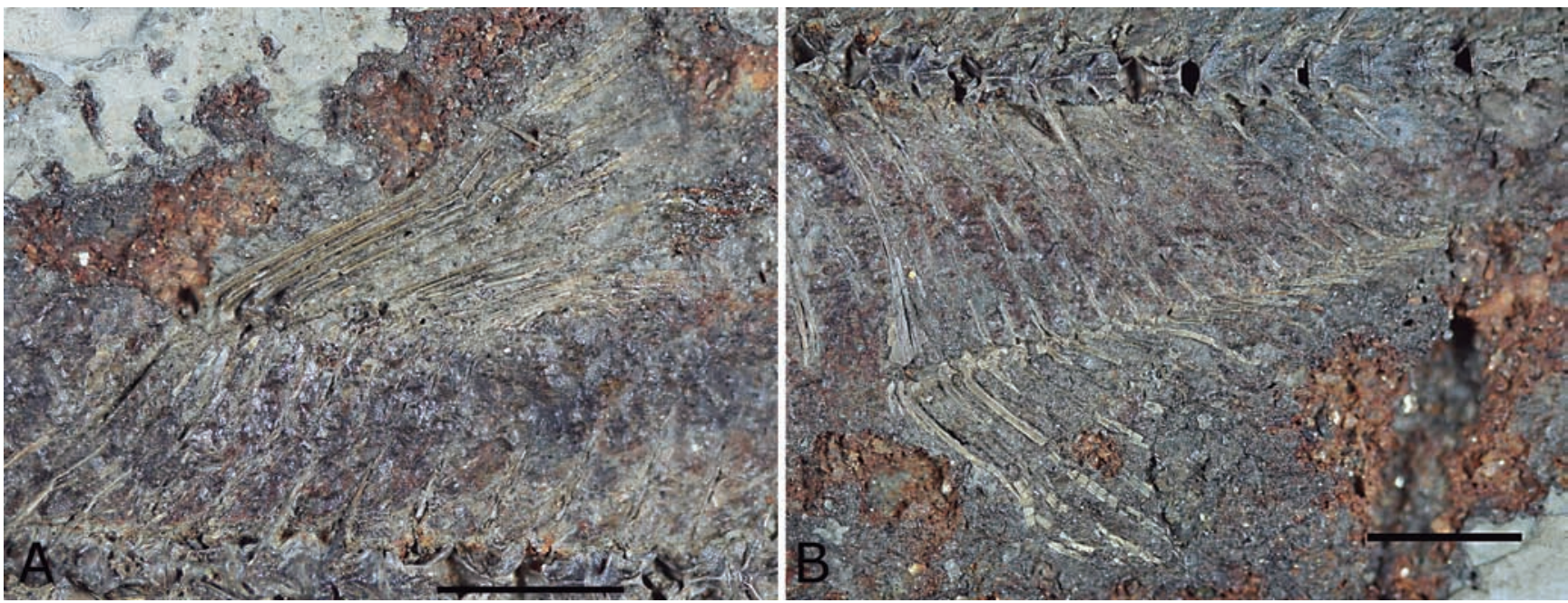

Fig. 5. $†$ Bryconetes enigmaticus n. gen. n. sp., holotype, UFRGS 19114. A, dorsal fin. B, anal fin. Scale bars $=5$ mm.

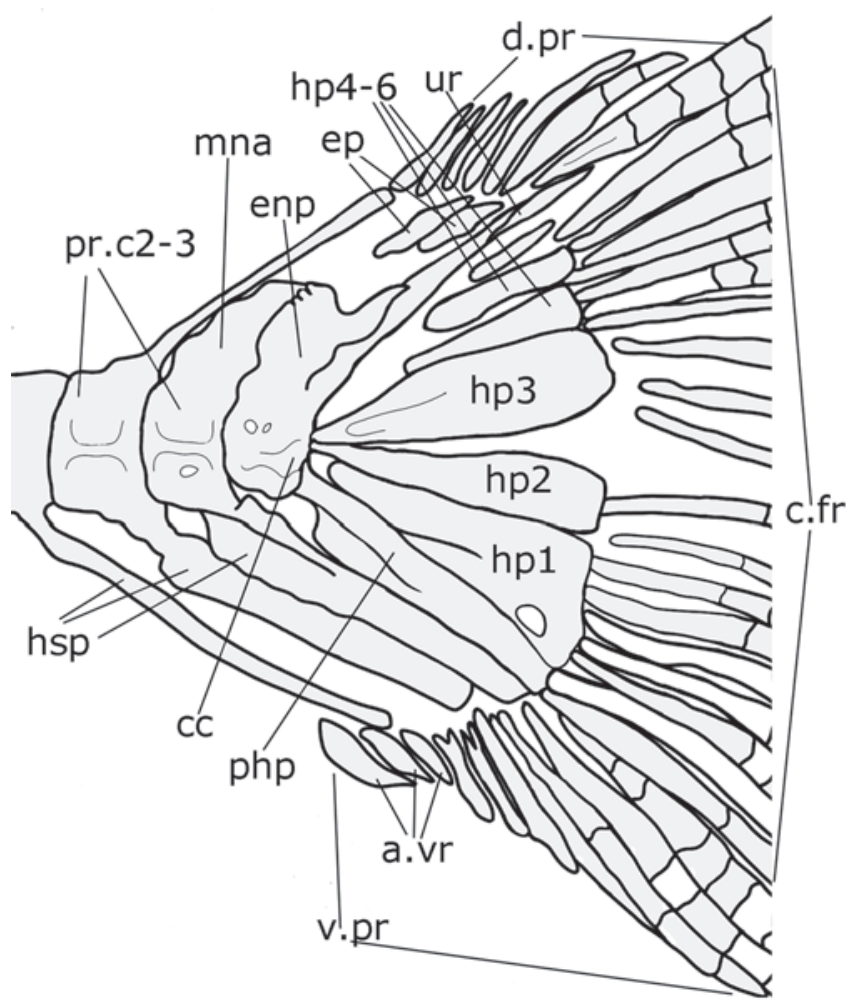

Fig. 6. Diagramatic representation of the caudal-fin skeleton of $†$ Bryconetes enigmaticus n. gen. $n$. sp. based on the holotype (UFRGS 19114). Abbreviations: a.vr, anterior ventral procurrent caudal-fin rays; cc, compound centrum; c.fr, principal caudal-fin rays; d.pr, dorsal procurrent caudal-fin rays; enp, especialized neural arch of compound centrum; ep, epurals; hp1-6, hypurals 1 to 6; hsp, haemal spine; mna, modified neural arch of preural centrum 2; php, parhypural; pr.c23 , preural centra 2-3; ur, uroneural; v.pr, ventral procurrent caudal-fin rays.

\section{Discussion}

\section{Characids from the Aiuruoca basin}

The fossil here described is the third characiform species from the Entre-Córregos Formation, in the Aiuruoca basin (Fig 1). The other two species were recently described (Weiss et al., 2012) and both belong to the genus Paleotetra: $P$. aiuruoca and $P$. entrecorregos, putatively assigned to the Characidae and Stevardiinae (sensu Mirande, 2010).

$\dagger$ Bryconetes enigmaticus differs from Paleotetra in the number of anal-fin rays (iii +23 in Bryconetes vs iv +21 in $P$. entrecorregos and iv+19 in P. aiuruoca), but these counts are usually variable among various species of the order. These differences cannot be taken as diagnostic since the counts were taken in a single specimen of each species.

Features that distinguish $\dagger$ Bryconetes enigmaticus from Paleotetra are the presence of a supraorbital (vs. absence), the presence of neuromast marks represented by punctuations and radial shallow grooves in the surface of the infraorbital 3 (vs. surface of infraorbital 3 smooth), the skeleton of the caudal fin with the most anterior ventral procurrent caudal-fin rays fused in laminar medial bones and the morphology of the preopercle. In $\dagger$ Bryconetes enigmaticus this bone has the surface deeply sculptured by the branches of the preopercular canal, whereas in Paleotetra only the canal openings mark the bony relief.

\section{Phylogenetic relationship of $†$ Bryconetes enigmaticus}

The fossil herein described presents a good preservation, allowing the recognition and identification of several anatomical structures. On the other hand, the lack of the snout prevents us to identify and discuss important diagnostic characters from the jaws and teeth. Therefore, the familial designation and relationships of $†$ Bryconetes enigmaticus is based on the presence or absence of characters that define monophyletic clades as discussed below. 
The presence of the Weberian apparatus in this fossil allows its inclusion in the Ostariophysi. Some characters presented by the Weberian elements (first four vertebrae shorter than the posterior ones and the remains of a tripus) and by the caudal skeleton (presence of a terminal compound centrum which is fused to the hypural 2) relate Bryconetes to the Otophysi.

Among the Otophysi, the new taxon is easily related to the Characiformes based on the presence of three synapomorphies of this order (Fink \& Fink, 1981, 1996): a posttemporal fossa, multicuspidate teeth, and a gap between the hypural 1 and the compound centrum of the caudal fin.

Within the Characiformes, recent phylogenetic analysis resulted in systematics rearrangements that make the recovery of $\dagger$ Bryconetes enigmaticus relationships more difficult. It can be assigned to the Characidae as former defined (Buckup, 1998; Mirande, 2009, 2010) by the presence of some synapomorphies listed for this family by Mirande (2010): the most anterior ventral procurrent caudal-fin rays fused in laminar medial bones (char. 305), a slender orbitosphenoid, relatively small and separate from parasphenoid (char. 37), and the presence of a rhinosphenoid (char. 47). The long anal fin that characterizes most of the members of this family (Géry, 1977), and the tooth shape (multicuspidate, strong and inflated) also corroborates such an assignment, being comparable to those found in some representatives of the former Characidae. Among Neotropical characiforms, only members of the Gasteropelecidae present similar teeth, but these share highly modified pectoral girdles with expanded coracoids, not observed in the fossil. Therefore, this combination of characters allows us to relate $\dagger$ Bryconetes enigmaticus to the Characidae as formerly defined.

Table 1. Morphometric and meristic data of †Bryconetes enigmaticus holotype (UFRGS 19114).

\begin{tabular}{lc}
\hline \multicolumn{1}{c}{ Character } & UNG 2T-152 \\
\hline \multicolumn{1}{c}{$\quad$ Percents of standard length } \\
\multicolumn{1}{c}{ Stand length (mm) } \\
Head length & 25.91 \\
Head depth & 23.49 \\
Greatest body depth & 30.52 \\
Snout to anal-fin origin & 62.67 \\
Snout to dorsal-fin origin & 48.01 \\
Snout to pelvic-fin origin & 45.10 \\
Anal-fin base length & 26.59 \\
Caudal peduncle length & 13.29 \\
Caudal peduncle depth & 11.62 \\
Dorsal-fin length & 21.34 \\
Pelvic-fin length & 14.89 \\
Pectoral-fin length & 18.08 \\
& \\
Snout length Percents of head length & 24.73 \\
Postorbital distance & 42.53 \\
Eye diameter & 27.29 \\
& \\
Pectoral fin rays & - \\
Dorsal fin rays & ii + 9 \\
Anal fin rays & iii + 23 \\
Vertebrae & $17 \mathrm{~A}+19 \mathrm{C}$ \\
\hline
\end{tabular}

The former Characidae includes a large internal monophyletic clade defined by the lack of a supraorbital bone and by the hyoid artery emerging from the anterior ceratohyal (Malabarba \& Weitzman, 2003; Mirande, 2009, 2010), that is also supported as monophyletic based on molecular data (Calcagnotto et al., 2005; Javonillo et al., 2010; Oliveira et al., 2011). The presence of a supraorbital bone in $\dagger$ Bryconetes enigmaticus does not allow its assignment to this clade. An implied weighting analysis of the matrix of Mirande (2010) actually places the fossil species as a stem group inside Characidae, as formerly defined, and outside the clade formed by those characiforms lacking a supraorbital.

A remarkable character observed in the fossil is the presence of diminutive punctuations and shallow grooves in the lateral surface of the infraorbital 3. These sculptures in the lateral surface of this infraorbital are similar to the diminutive scattered pores described in Acanthocharax, Acestrocephalus, Charax, Cynopotamus, Galeocharax, Phenacogaster, and Roeboides, and to the narrow grooves arranged radially or perpendicularly in relation to the orbit in Acestrocephalus, Charax, Phenacogaster, and Roeboides (Mattox \& Toledo-Piza, 2012: fig. 19A-D). These pores and grooves are associated to superficial neuromasts usually arranged in pitlines and constitutes a synapomorphy for the Characinae. Superficial neuromasts are further observed in other three unrelated characid groups: Astyanax hubbsi and A. mexicanus (Teyke, 1990), Coptobrycon bilineatus (Langeani \& Serra, 2010) and as a synapomorphy of Spintherobolus (Weitzman \& Malabarba, 1999) + Amazonspinther (Bührnheim et al., 2008). All these taxa, however, lack a supraorbital, are more deeply inserted in the phylogeny of the Characidae and cannot be hypothesized as closely related to †Bryconetes enigmaticus. The ornamentation of the infraorbital 3 , however, strongly suggests the presence of superficial neuromasts, even though the neuromasts themselves are not preserved in fossils.

The monophyletic clade containing characid species lacking a supraorbital has been erected as the Characidae in a restricted definition, but such a restriction was associated with the rearrangement of the members of the former Characidae that possess a supraorbital (Acestrorhynchinae, Agoniatinae, Bryconinae, Bryconops clade, Cynodontinae, Heterocharacinae, Iguanodectinae and Salmininae, sensu Mirande, 2010) into three new characiform families, the Bryconidae (= Bryconinae + Salmininae), Iguanodectidae (= Iguanodectinae + Bryconops), and Triportheidae (= Agoniatinae + Clupeacharacinae + Engraulisoma + Lignobrycon + Triportheus), as well as the transference of Heterocharacinae and Roestinae to the family Acestrorhynchidae (Oliveira et al., 2011). Contrasting with the previous wide acceptance of a large monophyletic clade containing all characid species lacking a supraorbital as monophyletic, all these new or rearranged families have been proposed based exclusively on the topology of a single molecular tree. Then, the compositions of these families differ 
from their previous molecular and morphological definitions, even at subfamily level, and completely lack morphological diagnoses, being useless to classify the fossil species, or even extant taxa without molecular data. In such a scenario, our comparison of possible relationships of Bryconetes is directed to those groups within former Characidae as previously and morphologically defined by several authors. We cannot conclusively demonstrate, however, a close relationship between $†$ Bryconetes enigmaticus and any of the above mentioned groups.

$\dagger$ Bryconetes enigmaticus does not possess any of the four synapomorphies listed for the Acestrorhynchidae sensu Menezes (2003): the presence of teeth in the ecto and endopterygoid; the first infraorbital covering almost completely the maxila; the presence of a branch of infraorbital canal in the premaxilla; and the rhinosphenoid in close contact with parasphenoid. Two of the seven synapomorphies of Roestinae sensu Lucena \& Menezes (1998) are absent in $\dagger$ Bryconetes enigmaticus: a pronounced concavity on posteroventral region of orbitosphenoid, and the presence of a bridge formed by dorsolateral extension of coracoid and median blade of cleithrum. $\uparrow$ Bryconetes enigmaticus shares with the Heterocharacinae one of the seven synapomorphies listed by Mattox \& Toledo-Piza (2012): the absence of suprapreopercle, but it completely lacks four of the synapomorphies that define the Heterocharacinae: the posteroventral margin of the orbitosphenoid with notch forming long posteriorly directed spiniform process; the absence of posterolateral spiniform projection on pterotic; the aligment of the distal margins of maxillary teeth rounded due to gradual anteroposteriorly increase and decrease in size of teeth on anterior portion of maxilla; and the distal radials of anal fin gradually less ossified posteriorly with the posteriormost ones being completely cartilaginous. The remaining synapomorphies listed by Lucena \& Menezes (1998) or Mattox \& Toledo-Piza (2012) were not preserved and could not be observed in the fossil.

Only two of the nine synapomorphies listed for the Bryconops clade by Mirande (2010) could be observed in the fossil. As Bryconops, the fossil possesses a branching of laterosensory canals of fourth or fifth infraorbitals; however, it has only 11 ventral procurrent caudal-fin rays versus 12 or more in the Bryconops clade.

The Iguanodectinae was defined by Vari (1977) based on three characters of the gas bladder that are not preserved in the fossil. Among the 19 synapomorphies listed for this subfamily by Mirande (2010), six are not present in $\dagger$ Bryconetes enigmaticus: the sixth infraorbital leaving a conspicuous naked area in the anterior region of the dilator fossa; the unbranched laterosensory canal of sixth infraorbital; the posterior extent of the maxilla not reaching the second infraorbital; the presence of a longitudinal ridge in quadrate bordering adductor mandibulae muscle ventrally and, to some degree, laterally; the articulation between quadrate and anguloarticular anterior to or at the vertical through lateral ethmoid; and the presence of four or more anal pterygiophores anterior to the first haemal spine. Four of these 19 synapomorphies are shared with the fossil species: the ventral extent of third infraorbital reaching the horizontal arm of preopercle; the posterior extent of ventral process of quadrate falling short of posterior margin of symplectic; the absence of supraneural anterior to neural spine of fourth vertebra; and the absence or reduced number of radii on scales. The nine remaining sinapomorphies were not preserved and are not observable in the fossil.

Due to the lack of a preserved premaxilla, the three characters listed as synapomorphies for Byconinae by Mirande (2010) could not be verified in the fossil. Among the 29 synapomorphies listed for the genera Lignobrycon and Triportheus by Mirande (2010), nine are not present in $\dagger$ Bryconetes enigmaticus: the form of fourth infraorbital longer dorsoventrally than longitudinally; the absence of branching of laterosensory canal in the fourth or fifth infraorbitals; the suprapreopercle autogenous; presence of a medial laminar expansion at dorsal tip of cleithrum; cleithrum ending dorsally in a position just dorsal of tip of mesocoracoid; the medial lamella of coracoid expanded as a keel; and the anteriormost epineurals reaching to cranium. On the other hand, six of the 19 synapomorphies are shared with the fossil species: third infraorbital extended ventrally and reaching the horizontal arm of preopercle; the implantation of teeth along maxilla not reaching the middle of maxillary lamella; 40 or fewer vertebrae; six or less branched pelvic-fin rays; the ventral process of quadrate not reaching the posterior margin of the symplectic; and the base of the second pectoral-fin ray similar in form and size to those of the posterior rays. The remaining characters were not preserved and are not observable in the fossil.

$\dagger$ Bryconetes enigmaticus lacks 8 of the 24 synapomorphies listed for the Cynodontidae sensu Toledo-Piza (2000): a great expansion of dilatator fossa to cover most of the dorsal surface of frontal; the lack of a shelf on frontal at posterodorsal edge of orbit; ectopterygoid teeth arranged in a patch covering most of or the entire surface of the ectopterygoid; the presence of a foramen for dentary canine in the anterior portion of the snout, with the ascending process of the maxilla shifted posteriorly, not contacting the premaxilla and forming the posterior and lateromedial portion of foramen; lack of direct contact between neural complex of Weberian apparatus and posterior margin of neurocranium; the elongate parapophyses of precaudal vertebrae, with parapophysis of one vertebra extending anteriorly and articulating with the anterior vertebra; enlarged coracoids; and the anterior portion of cleithrum ending in a vertically elongate process that articulates with the anterior portion of the enlarged coracoids. The remaining characters were not preserved and are not observable in the fossil.

Available information place $†$ Bryconetes enigmaticus as a member of clade 178 (Characidae sensu Mirande, 2010), but not included in his clade 204 (Characidae taxa lacking a supraorbital). According to the morphological information it 
is also a member of clade 34 of Oliveira et al. (2011) that comprises nearly the same groups included in Mirande's clade 178 , but it is not part of clade 51 (taxa lacking a supraorbital, Characidae sensu Oliveira et al., 2011 and nearly corresponding to Mirande's clade 204). Although sharing some synapomorphies with Bryconops and Heterocharacinae, we cannot clearly assign $\dagger$ Bryconetes enigmaticus to any of these groups, placing the fossil as a stem group to characid characiforms lacking a supraorbital.

Comparative material. Fossil (indicated by $\dagger$ throughout this paper) and modern characids were used for comparing with $†$ Bryconetes enigmaticus: Brycon melanopterus, UFRGS 10373, $51.3 \mathrm{~mm}$ SL, cleared and stained, partially disarticulated. Bryconops giacopinni, UFRGS 10368, $50.5 \mathrm{~mm}$ SL and $65.6 \mathrm{~mm}$ SL, cleared and stained specimens. Pseudocorynopoma doriae, UFRGS 8340, $51.3 \mathrm{~mm}$ SL, cleared and stained. †Paleotetra aiuruoca, UNG 2T151, holotype. †Paleotetra entrecorregos, UNG 2T-149, holotype.

\section{Acknowledgements}

We especially thank M. J. Garcia for helping in collecting expeditions and documenting the Aiuruoca basin stratigraphy. The authors greatly appreciated the financial support provided by the Conselho de Desenvolvimento Científico e Tecnológico (CNPq, Brazil) through a fellowship to FEW, a fellowship 401824/2010-1 and grant 151054/2013-4 to MCM, and a fellowship 300705/2010-7 and research grant 477318/ 2012-6 supporting LRM.

\section{Literature Cited}

Arratia, G. 1997. Basal teleosts and teleostean phylogeny. Palaeo Ichthyologica, 7: 5-168

Arroyave, J., J. S. S. Denton \& M. L. J. Stiassny. 2013. Are characiform fishes Gondwanan in origin? Insights from a timescaled molecular phylogeny of the Citharinoidei (Ostariophysi: Characiformes). PLoS ONE 8(10): e77269. doi:10.1371/ journal.pone.0077269

Bedani, E. F. \& C. B. Haddad. 2002. Estudos preliminares de anfíbios (Anura: Pipidae) na Formação Entre-Córregos, Bacia de Aiuruoca, Terciário do estado de Minas Gerais, Brasil. Revista Universidade de Guarulhos, 6: 35-42.

Bertini, R. J., L. G.Marshall, M. Gayet \& P. Brito. 1993. Vertebrate faunas from the Adamantina and Marília formations (Upper Bauru Group, late Cretaceous, Brazil) in their stratigraphic and paleobiogegraphic context. Neues Jahrbuch für Geologie und Paläontologie, Abhandlungen, 188: 71-101.

Buckup, P. 1998. Relationship of the Characidiinae and phylogeny of characiform fishes (Teleostei: Ostariophysi). Pp. 123-144. In: Malabarba, L. R., R. E. Reis, R. P. Vari, Z. S. Lucena \& C. S. Lucena (Eds.). Phylogeny and Classification of Neotropical Fishes. Porto Alegre, Edipucrs.

Bührnheim, C. M., T. P. Carvalho, L. R. Malabarba \& S. H. Weitzman. 2008. A new genus and species of characid fish from the Amazon basin - the recognition of a relictual lineage of characid fishes (Ostariophysi: Cheirodontinae: Cheirodontini). Neotropical Ichthyology, 6: 663-678.
Calcagnotto, D., S. A. Schaefer \& R. Desalle. 2005. Relationships among characiform fishes inferred from analysis of nuclear and mitochondrial gene sequences. Molecular Phylogenetics and Evolution, 36: 135-153.

Castro-Fernandes, M. C., M. E. Bernardes-de-Oliveira \& A. Hoelzel. 2013. Tafoflora Paleógena da Formação Entre-Córregos (Bacia de Aiuruoca): Arquitetura Foliar e Paleoclima. Revista do Instituto de Geociências USP, 13: 3-46.

Delgado, S. G. F. \& M. E. Bernardes-de-Oliveira. 2004. Annonaceae e Lauraceae da Formação Entre-Córregos (Paleógeno) na bacia de Aiuruoca: implicações paleoclimáticas. Revista Brasileira de Paleontologia, 7: 117-126.

Eschmeyer, W. N. \& J. D. Fong, 2014. Species by Family/Subfamily. Available from http://research.calacademy.org/reserch/ ichthyology/catalog/SpeciesByFamily.asp (Accessed on 04 february 2014).

Fink, S. V. \& W. L. Fink. 1981. Interrelationships of the ostariophysan fishes (Teleostei). Zoological Journal of Linnean Society, 72: 297-353.

Fink, S. V. \& W. L. Fink. 1996. Interrelationships of ostariophysan fishes (Teleostei). Pp. 209-249. In: Stiassny, M., L. Parenti, \& D. Johnson (Eds.). Interrelationships of Fishes. San Diego, Academic Press.

Fink, W. L. \& S. H. Weitzman. 1974. The so-called cheirodontin fishes of Central America with descriptions of two new species (Pisces: Characidae). Smithsonian Contributions to Zoology, 172: 1-46.

Garcia, M. J., M. Santos \& Y. Hasui. 2000. Palinologia da parte aflorante da Formação Entre-Córregos, Bacia de Aiuruoca, Terciário do Estado de Minas Gerais, Brasil. Revista Universidade de Guarulhos, 5: 259.

Gayet, M., M. Jégu, J. Bocquentin, \& F. R. Negri. 2003. New characoids from the Upper Cretaceous and Paleocene of Bolivia and the Mio-Pliocene of Brazil: phylogenetic position and paleobiogeographic implications. Journal of Vertebrate Paleontology, 23: 28-46.

Géry, J. 1977. Characoids of the world. Neptune City, T. F. H. Publications.

Javonillo, R., L. R. Malabarba, S. H. Weitzman \& J. R. Burns. 2010. Relationships among major lineages of characid fishes (Teleostei: Ostariophysi: Characiformes), based on molecular sequence data. Molecular Phylogenetics and Evolution, 54: 498-511.

Langeani, F. \& J. P. Serra. 2010. Coptobrycon bilineatus (Ellis, 1911) (Characiformes: Characidae): redescription and comments on its phylogenetic relationships. Neotropical Ichthyology, 8(4): 727-736.

Lucena, C. A. \& N. A. Menezes. 1998. A phylogenetic analysis of Roestes Günther and Gilbertolus Eigenmann, with a hypothesis of the relationships of the Cynodontidae and Acestrorhynchidae (Teleostei: Ostariophysi: Characiformes). Pp. 261-277. In: Malabarba, L. R., R. E. Reis, R. P. Vari, Z. S. Lucena \& C. S. Lucena (Eds.). Phylogeny and Classification of Neotropical Fishes. Porto Alegre, Edipucrs.

Malabarba, L. R. \& S. Weitzman. 2003. Description of a new genus with six new species from southern Brazil, Uruguay and Argentina, with a discussion of a putative characid clade (Teleostei: Characiformes: Characidae). Comunicações do Museu de Ciências e Tecnologia, 16: 67-151.

Malabarba, M. C. 1998. Phylogeny of fossil Characiformes and paleobiogeography of the Tremembé Formation, São Paulo, Brazil. Pp. 69-84. In: Malabarba, L. R., R. E. Reis, R. P. Vari, Z. 
S. Lucena \& C. S. Lucena (Eds.). Phylogeny and Classification of Neotropical Fishes. Porto Alegre, Edipucrs.

Malabarba, M. C. 2004. On the paleoichthyofauna from the Aiuruoca Tertiary Basin, Minas Gerais State, Brazil. Ameghiniana, 4: 515-519.

Malabarba, M. C. \& M. F. A. Dutra. 2002. Fossil fish remains from the Solimões Formation (Miocene) of the state of Amazonas, Brazil. Acta Geologica Leopoldensia, 54: 11-19.

Malabarba, M. C. \& L. R. Malabarba. 2008. A new cichlid Tremembichthys garciae (Actinopterygii, Perciformes) from the Eocene-Oligocene of eastern Brazil. Revista Brasileira Paleontologia, 11: 59-68.

Malabarba, M. C. \& L. R. Malabarba. 2010. Biogeography of Characiformes: an evaluation of the available information of fossil and extant taxa. Pp. 317-336. In: Nelson, J. S., H-P. Schultze \& M. V. H. Wilson (Eds.). Origin and Phylogenetic Interrelationships of Teleosts. München, Pfeil.

Mattox, G. \& M. Toledo-Piza. 2012. Phylogenetic study of the Characinae (Teleostei: Characiformes: Characidae). Zoological Journal of Linnean Society, 165: 809-915.

Menezes, N. A. 2003. Family Acestrorhynchidae. Pp. 231-233. In: Reis, R. E., S. O. Kullander \& C. J. Ferraris (Eds.). Check List of the Freshwater Fishes of South and Central America. Porto Alegre, Edipucrs.

Mirande, J. M. 2009. Weighted parsimony phylogeny of the family Characidae (Teleostei: Characiformes). Cladistics, 25: 574-613.

Mirande, J. M. 2010. Phylogeny of the family Characidae (Teleostei: Characiformes): from characters to taxonomy. Neotropical Ichthyology, 8: 385-568.

Oliveira, C., G. S. Avelino, K. Abe, T. C. Mariguela, R. C. Benine, G. Orti, R. P. Vari \& R. C. Castro. 2011. Phylogenetic relationships within the speciose family Characidae (Teleostei: Ostariophysi: Characiformes) based on multilocus analysis and extensive ingroup sampling. BMC Evolutionary Biology, 11: 275.

Reis, R. E., S. O. Kullander \& C. J. Ferraris 2003. Check list of the fishes of South and Central America. Porto Alegre, Edipucrs.

Richter, M. 1984. Dental histology of a characoid fish from the Plio-Pleistocene of Acre Brazil. Zoologica Scripta, 1: 69-79.

Ricominni, C., L. G. Sant'anna \& A. L. Ferrari. 2004. Evolução geológica do rift continental do sudeste do Brasil. Pp. 383-405. In: Mantesso, V., A. Bartorelli, C. R. Carneiro \& B. B. Neves (Eds.). Geologia do continente sul-americano: evolução da obra de Fernando Flávio Marques de Almeida. São Paulo, Beca.

Santos, M. 1999. Serra da Mantiqueira and Planalto do Alto Rio Grande: a Bacia Terciária de Aiuruoca e evolução morfotectônica. Unpublished Ph.D. Dissertation, Universidade Estadual Paulista, São Paulo, 225p.

Santos, M., Y. Hasui, N. Morales \& F. B. Ladeira. 2006. A Bacia Terciária de Aiuruoca: contribuição para o entendimento da evolução tectônica cenozóica do sul de Minas Gerais. Boletim do Simpósio Cretáceo do Brasil, 7: 114.

Schaeffer, B. 1947. Cretaceous and Tertiary actinopterygian fishes from Brazil. Bulletin of the American Museum of Natural History, 89: $1-40$.

Silva Santos, R. S. 1946. Uma nova espécie de caracídeo do Terciário do Maranhão, Brasil. Notas Preliminares e Estudos, 36: 1-3.

Teyke, T. 1990. Morphological differences in neuromasts of the blind cave fish Astyanax hubbsi and the sighted river fish Astyanax mexicanus. Brain, Behaviour and Evolution, 35: 23-30.

Toledo-Piza, M. 2000. The Neotropical fish subfamily Cynodontinae (Teleostei: Ostariophysi: Characiformes): a phylogenetic study and a revision of Cynodon and Rhaphiodon. American Museum Novitates, 3286: 1- 88

Travassos, H. \& R. S. Santos. 1955. Caracídeos fósseis da Bacia do Paraíba. Anais da Academia Brasileira de Ciências, 3: 297-322.

Vari, R. P. 1977. Notes on the characoid subfamily Iguanodectinae, with a description of a new species. American Museum Novitates, 2612: 1-6.

Weiss, F. E., L. R. Malabarba \& M. C. Malabarba. 2012. Phylogenetic relationships of Paleotetra, a new characiform fish (Ostariophysi) with two new species from the EoceneOligocene of south-eastern Brazil. Journal of Systematic Palaeontology, 10: 73-86.

Weitzman, S. H. 1962. The osteology of Brycon meeki, a generalized characid fish, with an osteological definition of the family. Stanford Ichthyology Bulletin, 8: 1-77.

Weitzman, S. H. \& L. R. Malabarba. 1999. Systematics of Spintherobolus (Teleostei: Characidae: Cheirodontinae) from eastern Brazil. Ichthyology Exploration of Freshwaters, 10: 143.

Woodward, A. S. 1898. Considerações sobre alguns peixes Terciários dos chistos de Taubaté, Estado de São Paulo, Brasil. Revista do Museu Paulista, 3: 63-70.

Zanata, A. M. \& R. P. Vari. 2005. The family Alestidae (Ostariophysi, Characiformes): a phylogenetic analysis of a trans-Atlantic clade. Zoological Journal of Linnean Society, 145: $1-144$.

Submitted May 8, 2014 Accepted June 20, 2014 by George Mattox Published June 30, 2014

Appendix 1. Codification of the 365 characters in the morphological matrix of Mirande (2010) for $†$ Bryconetes enigmaticus.

???100???0 000?????00 0??11??00? ??00??0??0 ??00011??0 010?0??000 0000000000 ???1?10?00 000??001?? ????000?1?00?0?00000 1000000100

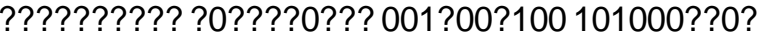
??000???0? ???10????? ?????????? ?????????? ?????????0 ???????0?? ?1000100?0 ?0000000?0 ??1???00?? ?10?0??000 ??01100??1 1000010001 000011100 ? ?000010?01 ?0?010???? ??????0010 ?????0???? ?????????0 ?????????? 0????????? ????? 